\title{
Geographically Weighted Spline Nonparametric Regression dengan Fungsi Pembobot Bisquare dan Gaussian Pada Tingkat Pengangguran Terbuka Di Pulau Kalimantan
}

\author{
Hillidatul Ilmi (1), Sifriyani ${ }^{(2)}$, Surya Prangga ${ }^{(3)}$ \\ Universitas Mulawarman \\ Jl. Barong Tongkok No. 4 Kampus Gunung Kelua, Samarinda, Kalimantan Timur 75123 \\ e-mail: hillidatul08ilmi@gmail.com ${ }^{(1)}$, sifriyani@fmipa.unmul.ac.id ${ }^{(2)}$, \\ suryaprangge@ gmail.com ${ }^{(3)}$
}

\begin{abstract}
ABSTRAK
Geographically weighted spline nonparametric regression merupakan pengembangan regresi nonparametrik untuk data spasial dengan estimator parameter bersifat lokal setiap lokasi pengamatan yang diaplikasikan pada kasus tingkat pengangguran terbuka. Tingkat pengangguran terbuka menjadi alat ukur kualitas kesejahteraan di suatu wilayah yang mengindikasikan besarnya persentase penduduk usia kerja yang aktif secara ekonomi. Tujuan penelitian ini yaitu untuk mengidentifikasi faktor-faktor yang mempengaruhi tingkat pengangguran terbuka 56 Kabupaten/Kota di Kalimantan. Metode yang digunakan adalah geographically weighted spline nonparametric regression dengan pembobot fungsi kernel eksponensial. Model terbaik geographically weighted spline nonparametric regression dengan pembobot fungsi kernel eksponensial pada orde 1 titik knot 1 dengan nilai $R$-Square sebesar 86,410 persen, nilai AIC sebesar 12,152, nilai RMSE sebesar 0,584 serta nilai CV terkecil adalah fungsi kernel bisquare sebesar 77,175. Adapun faktor-faktor yang berpengaruh signifikan terhadap tingkat pengangguran terbuka yaitu tingkat partisipan angkatan kerja, jumlah penduduk, indeks pembangunan manusia, harapan lama sekolah dan upah minimum.

Kata Kunci : Fungsi kernel bisquare, Fungsi kernel gaussian, geographically weighted spline nonparametric regression, tingkat pengangguran terbuka, titik knot.

\section{ABSTRACT}

Geographically weighted spline nonparametric regression is a nonparametric regression development for spatial data with a local parameter estimator for each observation location which is applied to the case of the open unemployment rate. The open unemployment rate is a measure of the quality of welfare in an area which indicates the large percentage of the working age population who are economically active. The purpose of this study is to identify the factors that influence the open unemployment rate in 56 regencies/cities in Kalimantan. The method used is geographically weighted spline nonparametric regression with weighted exponential kernel function. The best model is geographically weighted spline nonparametric regression with an exponential kernel function weighting on the order of 1 point knot 1 with an R-Square value of 86,410 percent, an AIC value of 12,152, an RMSE value of 0.584 and the smallest $C V$ value is a bisquare kernel function of 77.175. The factors that have a significant effect on the open unemployment rate are the level of labor force participation, population, human development index, school year expectations and minimum wages.
\end{abstract}

Keywords : bisquare kernel function, gaussian kernel function, geographically weighted spline nonparametric regression, open unemployment rate, knot points.

\section{PENDAHULUAN}

Analisis regresi yang digunakan untuk memodelkan data spasial dikenal model Geographically Weighted Regression (GWR). GWR pertama kali diperkenalkan oleh Fotheringham pada tahun 1967. GWR adalah salah satu model spasial dengan vektor titik. GWR merupakan pengembangan dari model regresi linier menjadi model regresi terboboti dengan

Hillidatul Ilmi ${ }^{1}$, Sifriyani ${ }^{2}$, Surya Prangga ${ }^{3} /$

J Statistika Vol. 14, No. 2, (2021) memperhatikan efek spasial, sehingga menghasilkan penduga parameter yang hanya dapat digunakan untuk memprediksi setiap titik atau lokasi di mana data tersebut diamati dan disimpulkan. Melalui model GWR akan menghasilkan interpretasi setiap titik lokasi yang diteliti akan berbeda-beda (Fotheringham, dkk, 2002). 
Model GWR yang dikembangkan masih dalam bentuk linear, yang hanya mampu mengatasi masalah analisis regresi spasial yang kurva regresinya diketahui dan linier. Dalam beberapa kenyataan yang dihadapi dalam analisis regresi tidak semua data berpola linier dan kurva regresinya diketahui. Model regresi yang baik, sebaiknya dipandang dari berbagai aspek dan menempatkan suatu persoalan pemodelan tepat pada porsinya. Perbedaan karakteristik lingkungan dan geografis antar lokasi pengamatan, mengakibatkan pengamatan memiliki variasi yang berbeda atau terdapat perbedaan pengaruh variabel prediktor terhadap variabel respon untuk setiap lokasi pengamatan. Bagaimana cara menyelesaikan apabila pengaruh variabel prediktor terhadap variabel respon tidak mengikuti pola tertentu dan terdapat pola yang berubah-ubah pada sub-sub interval tertentu. Dalam situasi ini model GWR belum mampu mengatasi masalah ini, sehingga sangat dipertimbangkan untuk mengembangkan penelitian dibidang regresi nonparametric dan statistika spasial.

Para ahli statitik mengembangkan penelitian tentang GWR diantaranya (Nakaya, Fotheringham, Brunsdon dan Charlton, 2005) mengembangkan Geographically Weighted Poisson Regression Models, selanjutnya (Mei, Wang dan Zhang, 2006) menghasilkan model yang menggabungkan model regresi global dan GWR yang dikenal Mixed Geographically Weighted Regression Models. Model GWR juga dikembangkan dalam bidang spasial yang berhubungan dengan timeseries yang dikenal dengan spatio-temporal, eksplorasi data spatio-temporal dianalisis dengan menggunakan GWR dan analitic geovisual, penelitian ini dilakukan oleh (Demsar, Fotheringham dan Charlton, 2008). Penelitian spatio-temporal juga digunakan oleh (Huang, Wu dan Barry, 2010) dalam Geographically And Temporally Weighted Regression Model. Selanjutnya (Yu, 2010) penelitian pada data panel spasial dengan menggunakan Geographically Weighted Panel Regression, dan penelitian oleh (Wrenn dan sam, 2014) digunakan model Geographically and Temporally Weighted Likelihood Regression. Penelitian sebelumnya mengembangkan model regresi nonparametric dalam GWR atau geographically weighted spline nonparametric regression (Sifriyani, 2018a).

Model geographically weighted spline nonparametric regression diaplikasikan untuk mendeteksi penyebaran kesejahterahan masyarakat melalui Tingkat Pengangguran Terbuka (TPT) dalam konteks spasial. Kajian epidemiologi spasial yang membahas bagaimana pengaruh bidang pendidikan, kependudukan dan ekonomi mempengaruhi kenaikan atau penurunan TPT (BPS, 2020). Kajian epidemiologi spasial yang membahas bagaimana pengaruh bidang pendidikan, kependudukan dan ekonomi mempengaruhi kenaikan atau penurunan TPT. Penetian ini tentang analisis TPT dalam Skala Daerah yang dapat membantu merumuskan kebijakan wilayah untuk 56 Kabupaten/Kota di Pulau Kalimantan dalam menurunkan penyebaran TPT yang berkelanjutan dan memperkuat pemahaman tentang epidemiologi spasial ekonomi tersebut. Artikel ini membahas identifikasi faktorfaktor yang mempengaruhi TPT 56 Kabupaten/kota di Pulau Kalimantan berdasarkan faktor di bidang pendidikan, bidang kependudukan dan ekonomi. Pada penelitian ini digunakan data penelitian TPT 56 Kabupaten/Kota di Pulau Kalimantan Tahun 2019.

Kebaharuan dalam penelitian ini, digunakan pengembangan model geographically weighted spline nonparametric regression dengan optimasi GCV yang menggunakan dua basis matriks fungsi polynomial dan fungsi truncated. Selanjutnya diperoleh uji signifikansi simultan dan parsial yang mendukung model geographically weighted spline nonparametric regression. Hasil model geographically weighted spline nonparametric regression setiap kelompok memiliki faktor pengaruh yang berbeda sehingga penanganan TPT setiap Kabupaten/Kota berbeda. Pengelompokan berdasarkan faktor-faktor yang mempengaruhi TPT yaitu Tingkat Partisipan Angkatan Kerja (TPAK), jumlah penduduk, Indeks Pembangunan Manusia (IPM), Harapan Lama Sekolah (HLS) dan upah minimum. Penelitian ini dapat memberikan konstribusi di bidang ekonomi dan pemerintah dapat menggunakan atau lebih memperhatikan faktor-faktor tersebut dalam membangun tingkat kesejahteraan di Pulau Kalimantan.

\section{METODE PENELITIAN}

\subsection{Data dan Sumber Data}

Data yang digunakan dalam penelitian ini adalah data cross section yang bersumber dari Badan Pusat Statistika Tahun 2019 dan Dinas Keternagakerjaan Tahun 2019. Deskripsi dan Sumber data pengamatan dalam penelitian ditampilkan pada Tabel 1.

Tabel 1. Deskripsi Variabel dan Sumber Data Pengamatan

Hillidatul Ilmi ${ }^{1}$, Sifriyani ${ }^{2}$, Surya Prangga ${ }^{3} /$

J Statistika Vol. 14, No. 2, (2021) 
J Statistika Vol. 14, No. 2, (2021), Hal. 84-92

\begin{tabular}{|c|c|c|c|c|}
\hline Variabel & & $\begin{array}{c}\text { Deskripsi } \\
\text { Variabel }\end{array}$ & Satuan & Skala \\
\hline Respon & $y$ & TPT & Persen & Kontinu \\
\hline \multirow{5}{*}{ Prediktor } & $x_{1}$ & TPAK & Persen & Kontinu \\
\cline { 2 - 5 } & $x_{2}$ & $\begin{array}{c}\text { Jumlah } \\
\text { Penduduk }\end{array}$ & Jiwa & Diskrit \\
\cline { 2 - 5 } & $x_{3}$ & IPM & Persen & Kontinu \\
\cline { 2 - 6 } & $x_{4}$ & HLS & Tahun & Kontinu \\
\cline { 2 - 5 } & $x_{5}$ & $\begin{array}{c}\text { Upah } \\
\text { Minimum }\end{array}$ & Rupiah & Kontinu \\
\hline
\end{tabular}

\subsection{Analisis Data}

Analisis pada penelitian ini dilakukan dengan bantuan microsoft excel, software $R$ 3.6.3 dan software octave. Berdasarkan tujuan dalam penelilitian ini, maka langkah-langkah sebagai berikut :

1. Membuat analisis statistika deskriptif dari masing-masing variabel yang terdiri dari mapping area, rata-rata, nilai minimum dan nilai maksimum. 2. Analisis pola linier menggunakan scatterplot antara variabel respon dengan masing-masing variabel prediktor.

3. Melakukan pendekteksian multikolineritas menggunakan nilai variance inflation factor (VIF) (Ghozali, 2016).

$$
\mathrm{VIF}=\frac{1}{1-R_{k}^{2}}
$$

Dengan $R_{k}^{2}=1-\frac{\sum\left(y_{i}-\hat{y}_{i}\right)^{2}}{\sum\left(y_{i}-\bar{y}\right)^{2}}$, dimana $\hat{y}_{i}$ adalah nilai prediksi model regresi nonparametrik variabel respon ke- $i$ dan $\bar{y}$ adalah nilai rata-rata variabel respon.

4. Heterogenitas spasial dengan metode Breusch Pagan, hipotesis : (Kosfeld, 2006).

$H_{0}: \sigma_{1}^{2}=\sigma_{2}^{2}=\ldots=\sigma_{n}^{2}=\sigma^{2}$

$H_{1}$ : Paling tidak ada satu $\sigma_{1}^{2} \neq \sigma_{n}^{2}$ dengan statistika uji :

$$
B P=\frac{1}{2} \mathbf{f}^{\mathrm{T}} \mathbf{Z}\left(\mathbf{Z}^{\mathrm{T}} \mathbf{Z}\right)^{-1} \mathbf{Z}^{\mathrm{T}} \mathbf{f}
$$

Dengan $\quad \mathbf{f}=\left(\frac{\varepsilon_{i}^{2}}{\sigma^{2}}-1\right) \quad$ dimana vektor $\mathbf{f}=\left(f_{1}, f_{2}, \ldots, f_{n}\right)^{T}$ dan $\varepsilon_{i}=y_{i}-\hat{y}_{i}$. Matriks $\mathbf{Z}$ merupakan matriks yang berisi vektor pengamatan www.unipasby.ac.id

variabel respon. Tolak $H_{0}$ jika $B P>\chi_{(k)}^{2}$ atau $p$-value $<\alpha$ dengan $k$ adalah banyaknya prediktor.

5. Menghitung jarak eucliden antara lokasi ke-i yang terletak pada koordinat terhadap lokasi ke-j (Fotheringham, dkk, 2002).

$$
d_{i j}=\sqrt{\left(u_{i}-u_{j}\right)^{2}+\left(v_{i}-v_{j}\right)^{2}}
$$

$d_{i j}$ adalah jarak euclidian antara lokasi $\left(u_{i}, v_{i}\right)$ dan lokasi $\left(u_{j}, v_{j}\right)$.

6. Menghitung matriks pembobot geografis, dengan menggunakan fungsi pembobot georafis (Sifriyani, dkk, 2019), (Sifriyani, dkk, 2019a), (Sifriyani, dkk, 2019b). Fungsi Kernel Gaussian

$$
w_{j}\left(u_{i}, v_{i}\right)=\exp \left(-\frac{1}{2}\left(\frac{d_{i j}}{h}\right)^{2}\right)
$$

dan Fungsi Kernel Bisquare

$$
w_{j}\left(u_{i}, v_{i}\right)=\left\{\begin{array}{c}
\left(1-\left(\frac{d_{i j}}{h}\right)^{2}\right)^{2}, \text { untuk } \mathrm{d}_{\mathrm{ij}} \leq \mathrm{h} \\
0, \text { untuk } \mathrm{d}_{\mathrm{ij}}>\mathrm{h}
\end{array}\right.
$$

$h$ adalah parameter non-negatif yang diketahui dan biasanya disebut parameter penghalus (bandwidth).

7. Menentukan titik knot optimum dengan menggunakan metode pengembangan Generalized Cross Validation (GCV) (Eubank, 1998).

$$
\mathrm{GCV}=\frac{\operatorname{MSE}(K)}{\left(n^{-1} \text { trace }[\mathrm{I}-A(K)]\right)^{2}}
$$

Dengan $\operatorname{MSE}(K)=\frac{1}{n} \sum_{i=1}^{n}\left(y_{i}-\hat{f}\left(x_{i}\right)\right)^{2}, \quad I \quad$ adalah matriks identitas, $K$ adalah titik knot $K_{1}, K_{2}, \ldots, K_{r}, \quad A(K) \quad$ adalah matriks $\mathbf{X}\left(\mathbf{X}^{T} \mathbf{V X}\right)^{-1} \mathbf{X}^{T} \mathbf{V}$ dan trace adalah jumlah dari elemen diagonal utama dari matriks kuadrat.

8. Melakukan estimator model geographically weighted spline nonparametric regression dengan pembobot geografis (Sifriyani, dkk, 2018a).

$$
\begin{aligned}
\hat{\boldsymbol{\beta}}\left(u_{i}, v_{i}\right) & =\mathbf{A}(\mathbf{K}) \mathbf{y} \\
\hat{\boldsymbol{\delta}}\left(u_{i}, v_{i}\right) & =\mathbf{B}(\mathbf{K}) \mathbf{y}
\end{aligned}
$$

Dimana $\hat{\boldsymbol{\beta}}\left(u_{i}, v_{i}\right)$ merupakan estimator dari parameter $\boldsymbol{\beta}\left(u_{i}, v_{i}\right)$ dengan vektor ukuran 
$(1+(d \times p)) \times 1 \quad$ dan $\quad \hat{\boldsymbol{\delta}}\left(u_{i}, v_{i}\right) \quad$ estimator dari

parameter $\boldsymbol{\delta}\left(u_{i}, v_{i}\right)$ dengan vektor ukuran

$(d \times r) \times 1$.

9. Melakukan pengujian kesesuaian model, hipotesis : (Sifriyani, dkk, 2018b).

$H_{0}: \beta_{k f}\left(u_{i}, v_{i}\right)=\beta_{k f}$ dan $\delta_{k, m+s}\left(u_{i}, v_{i}\right)=$

$$
\delta_{k, m+s}
$$

$H_{1}$ : Paling tidak ada satu $\beta_{k f}\left(u_{i}, v_{i}\right) \neq \beta_{k f}$

atau $\delta_{k, m+s}\left(u_{i}, v_{i}\right) \neq \delta_{k, m+s}, k=1, \ldots, d$

$f=1, \ldots, p ; s=1, \ldots, r ; i=1, \ldots, n$

dengan Statistika uji :

$$
V=\frac{\frac{\mathbf{y}^{\mathrm{T}} \mathbf{S} \mathbf{y}}{n-l m-1}}{\frac{\mathbf{y}^{\mathrm{T}} \mathbf{D}\left(u_{i}, v_{i}\right) \mathbf{y}}{\operatorname{tr}\left((\mathbf{I}-\xi)^{\mathrm{T}}(\mathbf{I}-\xi)\right)}}
$$

dimana

$$
\begin{array}{r}
\mathbf{D}\left(u_{i}, v_{i}\right)=\left(\mathbf{I}-\mathbf{W}\left(u_{i}, v_{i}\right) \mathbf{Q}\left(\mathbf{Q}^{\mathbf{T}} \mathbf{W}\left(u_{i}, v_{i}\right) \mathbf{Q}\right)^{-1} \mathbf{Q}^{\mathbf{T}}\right) \\
\left(\mathbf{I}-\mathbf{Q}\left(\mathbf{Q}^{\mathbf{T}} \mathbf{W}\left(u_{i}, v_{i}\right) \mathbf{Q}\right)^{-\mathbf{1}} \mathbf{Q}^{\mathbf{T}} \mathbf{W}\left(u_{i}, v_{i}\right)\right) \\
\xi=\mathbf{Q}\left(\mathbf{Q}^{\mathbf{T}} \mathbf{W}\left(u_{i}, v_{i}\right) \mathbf{Q}\right)^{-\mathbf{1}} \mathbf{W}\left(u_{i}, v_{i}\right)
\end{array}
$$

Uji hipotesis untuk kesesuaian model, dengan y adalah vektor variabel respon, $n$ adalah banyaknya variabel respon, $l$ adalah banyaknya variabel prediktor, $m$ adalah orde fungsi spline dan I adalah matriks identitas. Kriteria penolakan $H_{0}$ adalah tolak $\quad H_{0}$ jika $\quad F_{\text {hitung }}(V)>F_{\left(\alpha ; d b_{1} ; d b_{2}\right)} \quad$ atau $p-$ value $<\alpha$.

10. Melakukan pengujian Signifikan Parameter Simultan, hipotesis : (Sifriyani, dkk, 2018b).

$$
\begin{aligned}
H_{0}: & \beta_{11}\left(u_{i}, v_{i}\right)=\beta_{12}\left(u_{i}, v_{i}\right)=\ldots=\beta_{d p}\left(u_{i}, v_{i}\right) \\
& =\delta_{1, m+1}\left(u_{i}, v_{i}\right)=\delta_{1, m+2}\left(u_{i}, v_{i}\right)=\ldots= \\
& \delta_{d, m+r}\left(u_{i}, v_{i}\right)
\end{aligned}
$$

$H_{1}$ : Paling tidak ada satu $\beta_{k f}\left(u_{i}, v_{i}\right) \neq 0$ atau

$$
\begin{aligned}
& \delta_{k, m+s}\left(u_{i}, v_{i}\right) \neq 0, k=1, \ldots, d ; f=1, \ldots, p ; \\
& s=1, \ldots, r ; i=1, \ldots, n
\end{aligned}
$$

dengan statistika uji :

Hillidatul Ilmi ${ }^{1}$, Sifriyani ${ }^{2}$, Surya Prangga ${ }^{3} /$

J Statistika Vol. 14, No. 2, (2021)

$$
V^{*}=\frac{\left(\frac{\mathbf{y}^{\mathrm{T}} \mathbf{M}\left(u_{i}, v_{i}\right) \mathbf{y}}{\operatorname{tr}\left(\left(\mathbf{I}-\mathbf{B}_{\omega}\right)^{\mathrm{T}}\left(\mathbf{I}-\mathbf{B}_{\omega}\right)\right)}\right)}{\left(\frac{\mathbf{y}^{\mathrm{T}} \mathbf{D}\left(u_{i}, v_{i}\right) \mathbf{y}}{\operatorname{tr}\left((\mathbf{I}-\xi)^{\mathrm{T}}(\mathbf{I}-\xi)\right)}\right)}
$$

Dimana $\mathbf{M}\left(u_{i}, v_{i}\right)=\left(\mathbf{I}-\mathbf{B}_{\omega}\right)^{\mathrm{T}}\left(\mathbf{I}-\mathbf{B}_{\omega}\right)$ dengan y adalah vektor variabel respon dan I adalah matriks identitas. Dan kriteria penolakan $H_{0}$ adalah tolak $H_{0}$ jika $F_{\text {hitung }}(V *)>F_{\left(\alpha ; d b_{1} ; d b_{2}\right)}$ atau $\quad p-$ value $<\alpha \quad$ (Sifriyani, Hayatmi, Budiantara, dkk., 2018b).

11. Melakukan pengujian hipotesis parsial atau pengujian pengaruh lokasi secara parsial pada setiap variabel prediktor, hipotesis : (Sifriyani, dkk, 2018b).

$H_{0}: \beta_{k f}\left(u_{i}, v_{i}\right)=0$ dan $\delta_{k, m+s}\left(u_{i}, v_{i}\right)=0$

$H_{1}$ : Paling tidak ada satu $\beta_{k f}\left(u_{i}, v_{i}\right) \neq 0$ atau

$$
\begin{aligned}
& \delta_{k, m+s}\left(u_{i}, v_{i}\right) \neq 0 ; k=1, \ldots, d ; f=1, \ldots, p ; \\
& s=1, \ldots, r ; i=1, \ldots, n
\end{aligned}
$$

dengan statiska uji :

$$
t=\frac{\hat{\boldsymbol{\eta}}\left(u_{i}, v_{i}\right)}{S E\left(\hat{\boldsymbol{\eta}}\left(u_{i}, v_{i}\right)\right)}
$$

$\hat{\boldsymbol{\eta}}\left(u_{i}, v_{i}\right)$ adalah Estimator dari $\boldsymbol{\eta}\left(u_{i}, v_{i}\right)$ dan $\operatorname{SE}\left(\hat{\boldsymbol{\eta}}\left(u_{i}, v_{i}\right)\right)$ adalah Elemen diagonal ke $k+1$ dari $\operatorname{matrik}\left(\mathbf{Q}^{T} \mathbf{W}\left(u_{i}, v_{i}\right) \mathbf{Q}\right)^{-1} \hat{\sigma}^{2}\left(u_{i}, v_{i}\right), \mathbf{Q}$ adalah matriks ukuran $n \times[1+(d \times p)+(d \times r)]$ yang memuat variabel prediktor dan variabel prediktor yang mempunyai komponen spline truncated.

12. Mendapatkan faktor-faktor yang mempengaruhi TPT 56 Kabupaten/Kota di Pulau Kalimantan.

13. Kesimpulan.

\section{HASIL DAN PEMBAHASAN}

3.1 Statistika Deskriptif

Deskripsi data penelitian meliputi analisis statistika deskriptif berupa nilai rata rata, nilai minimum serta nilai maksimum. Statistika deskriptif disajikan pada Tabel 1.

Tabel 1. Statistika Deskriptif Data Penelitian 
J Statistika Vol. 14, No. 2, (2021), Hal. 84-92

\begin{tabular}{|c|l|l|l|}
\cline { 2 - 4 } \multicolumn{1}{c|}{} & Rata-rata & Minimum & Maksimum \\
\hline$y$ & 4,355 & 1,740 & 9,190 \\
\hline$x_{1}$ & 69,04 & 61,62 & 77,19 \\
\hline$x_{2}$ & 288.967 & 26.400 & 872.800 \\
\hline$x_{3}$ & 70,41 & 62,66 & 80,77 \\
\hline$x_{4}$ & 12,67 & 11,15 & 14,99 \\
\hline$x_{5}$ & 2.753 .530 & 2.175 .200 & 3.462 .192 \\
\hline
\end{tabular}

Berdasarkan Tabel 1 Statistika deskripsi data penelitian TPT dari 56 Kabupaten/Kota di Kalimantan dapat dilihat bahwa rata-rata yang mewakili sekumpulan data TPT adalah 4,355 persen dengan TPT terendah ada di Kabupaten Pulang Pisau sebesar 1,740 persen dan tertinggi ada di Kota Bontang.

\subsection{Pola Hubungan Antar Variabel}

Indentifikasi pola hubungan mengunakan scatterplot, dimana data penelitian dapat berupa regresi parametrik, regresi semiparametrik atau regresi nonparametrik dengan melihat suatu pola tertentu (linier, kuadratik atau kubik). Berikut adalah hasil scatterplot pada TPT dengan beberapa variabel prediktor yang disajikan pada Gambar 1 :

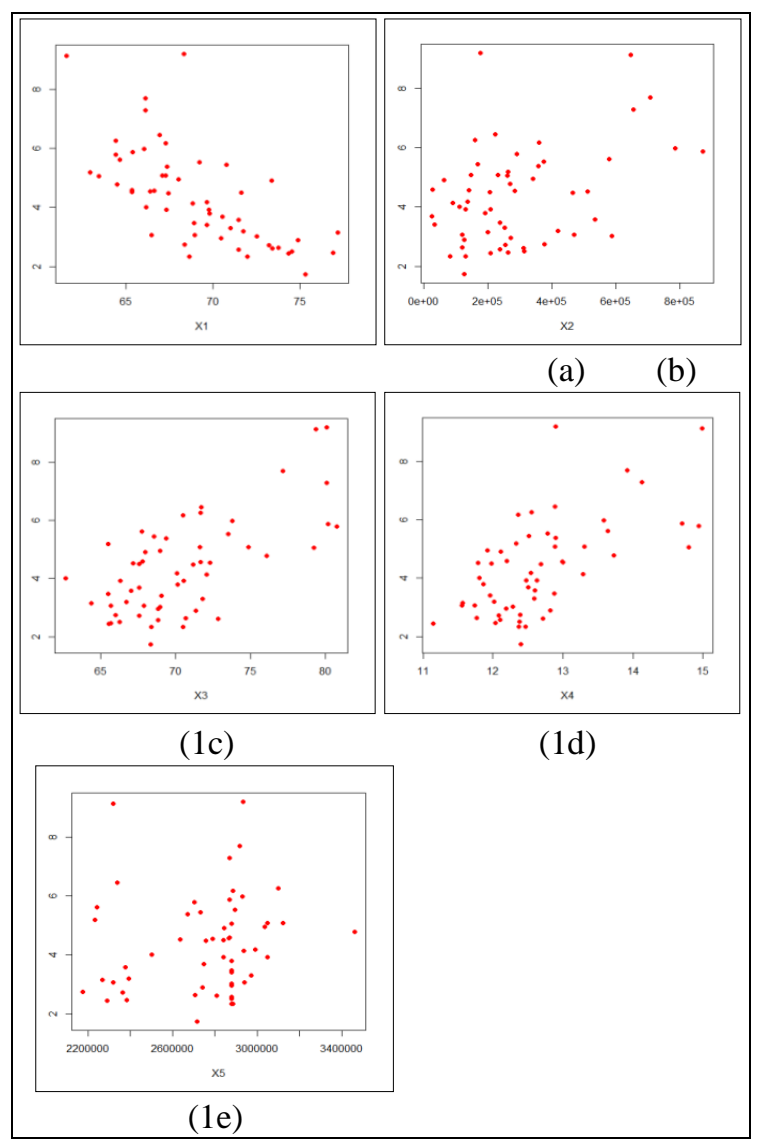

www.unipasby.ac.id

Gambar 1. Pola Hubungan Variabel Respon dengan Variabel Prediktor

Pola hubungan yang terbentuk antara variabel respon dengan masing-masing variabel prediktor tidak mengikuti pola tertentu dan terdapat pola yang berubah-ubah pada sub-sub interval tertentu. Perubahan ini dikarenakan setiap daerah menggunakan karakteristik yang berbeda-beda. Oleh karena itu metode geographically weighted spline nonparametric regression layak digunakan.

Tabel 2. Pendekteksian Multikolinearitas

\begin{tabular}{|c|c|c|c|c|}
\hline \multicolumn{5}{|c|}{ Nilai VIF } \\
\hline$x_{1}$ & $x_{2}$ & $x_{3}$ & $x_{4}$ & $x_{5}$ \\
\hline 1,551 & 1,456 & 4,132 & 4,370 & 1,488 \\
\hline
\end{tabular}

Pendekteksian multikolinieritas bertujuan untuk menguji apakah adanya korelasi antara variabel prediktor. Pendekteksian multikolinieritas menunjukkan bahwa tidak terjadi kolerasi karena nilai VIF <10, sehingga seluruh variabel prediktor bisa digunakan. Sedangkan pengujian heterogenitas spasial bertujuan untuk mengetahui apakah ada hubungan antara variabel respon dengan lokasi geografis.

Tabel 3. Breusch-Pagan Test

\begin{tabular}{|c|c|c|}
\hline Breusch-Pagan & Df & P-Value \\
\hline 19,988 & 10 & 0,048 \\
\hline
\end{tabular}

Hasil nilai maka keputuskan ditolak. Pengujian aspek spasial terpenuhi yaitu terdapat efek heterogenitas spasial maka kasus tingkat pengangguran terbuka dapat diselesaikan dengan menggunakan pendekatan titik.

\subsection{Peta Penyebaran Spasial}

Peta penyebaran spasial bertujuan untuk melihat visualisasi data penelitian yang akan dikelompkan secara pemetaan berdasarkan nilai masing-masing variabel setiap wilayah 56 Kabupaten/Kota di Kalimantan. Berikut masingmasing peta penyebaran data penelitian :

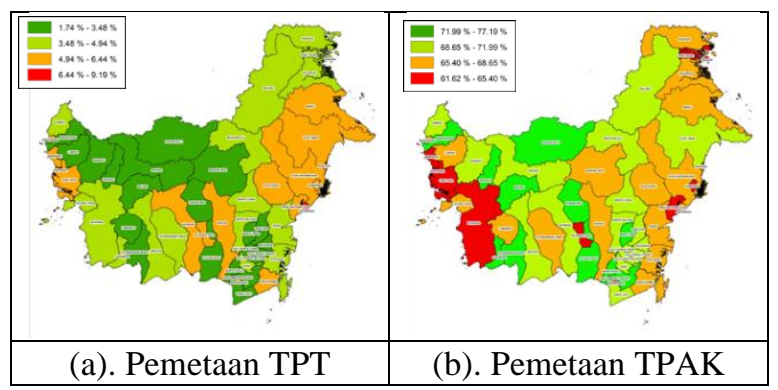

Hillidatul Ilmi ${ }^{1}$, Sifriyani ${ }^{2}$, Surya Prangga ${ }^{3} /$ 


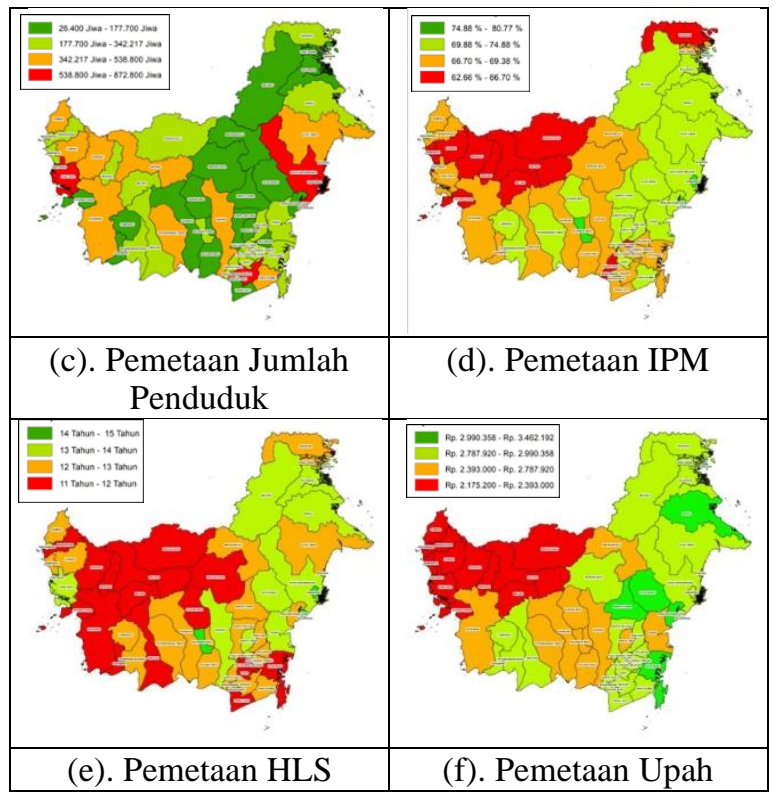

Gambar 1. Pemetaan Variabel Respon dan Variabel Prediktor 56 Kabupaten/Kota di Kalimantan

\subsection{Pemilihan Model Terbaik dan Titik Knot Optimum}

Pemilihan kriteria model terbaik dengan melihat nilai $R$-squared terbesar dari semua orde dan titik knot.

Tabel 4. Kriteria Model Terbaik

\begin{tabular}{|c|c|c|c|c|}
\hline Orde & $\begin{array}{c}\text { Titik } \\
\text { Knot }\end{array}$ & $\begin{array}{c}\boldsymbol{R} \text { - } \\
\text { squared }\end{array}$ & AIC & RMSE \\
\hline \multirow{3}{*}{1} & 1 & $\mathbf{8 6 , 4 1 1}$ & 12,152 & 0,584 \\
\cline { 2 - 5 } & 2 & 82,340 & 11,482 & 0,690 \\
\cline { 2 - 5 } & 3 & 81,319 & 11,303 & 0,722 \\
\hline
\end{tabular}

Berdasarkan kriteria $R$-squared, AIC serta RMSE dapat dilihat bahwa model orde 1 dan titik knot 1 adalah model geographically weighted spline nonparametric regression yang terbaik, dengan nilai $R$-squared sebesar 86,411 persen. Berdasarkan kriteria model terbaik maka diperlukan satu titik knot yang optimum menggunakan metode GCV untuk setiap variabel prediktor.

Tabel 4. Pemilihan Titik Knot Optimum dengan Satu Titik Knot

\begin{tabular}{|c|c|c|c|c|}
\hline No & $\boldsymbol{x}_{\mathbf{1}}$ & $\boldsymbol{x}_{\mathbf{2}}$ & $\boldsymbol{x}_{\mathbf{3}}$ & $\boldsymbol{x}_{\mathbf{4}}$ \\
\hline 1 & 71,585 & 568100 & 74,250 & 13,608 \\
\hline 2 & 69,716 & 466530 & 72,077 & 13,147 \\
\hline 3 & 69,872 & 474990 & 72,258 & 13,185 \\
\hline 4 & 71,429 & 559630 & 74,069 & 13,569 \\
\hline
\end{tabular}

Hillidatul Ilmi ${ }^{1}$, Sifriyani ${ }^{2}$, Surya Prangga ${ }^{3} /$

J Statistika Vol. 14, No. 2, (2021)

\begin{tabular}{|c|c|c|c|c|}
\hline 5 & 69,561 & 458060 & 71,896 & 13,108 \\
\hline No & $x_{5}$ & GCV & & \\
\hline 1 & 2998900 & 1,182 & & \\
\hline 2 & 2844400 & 1,184 & & \\
\hline 3 & 2857300 & 1,185 & & \\
\hline 4 & 2986000 & 1,186 & & \\
\hline 5 & 2831600 & 1,187 & & \\
\hline
\end{tabular}

Nilai GCV terkecil pada pemilihan titik knot optimum dengan satu titik knot yaitu 1,182. Sehingga didapatkan titik-titik knot optimum yaitu: $K_{11}=71,585, K_{21}=56.100, K_{31}=74,250, K_{41}=$ 13,608 dan $K_{51}=2.998 .900$.

\subsection{Pembobot Fungsi Kernel}

Matriks pembobot Spasial dengan fungsi Kernel Gaussian dan fungsi Kernel Bisquare pada lokasi pengamatan ke-1, ke-2 sampai ke-56.

Tabel 4. Nilai CV untuk Fungsi Pembobot

\begin{tabular}{|c|c|c|}
\hline Fungsi Pembobot & $\begin{array}{c}\text { Nilai } \\
\text { Bandwidth }\end{array}$ & GCV \\
\hline Fungsi Kernel Gaussian & 2,000 & 77,803 \\
\hline Fungsi Kernel Bisquare & 4,451 & $\mathbf{7 7 , 1 7 5}$ \\
\hline
\end{tabular}

Dari dua fungsi pembobot tersebut didapatkan funsi pembobot terbaik adalah pembobot fungsi kernel bisquare dengan nilai GCV lebih kecil dibandingkan dengan nilai GCV dari fungsi kernel gaussian sebesar 77,175.

\subsection{Uji Kesesuaian Model}

Bentuk hipotesis uji kesesuaian model sebagai berikut :

$H_{0}: \beta_{k f}\left(u_{i}, v_{i}\right)=\beta_{k f}$ dan $\delta_{k, m+s}\left(u_{i}, v_{i}\right)=\delta_{k, m+s}$

$H_{1}$ : Paling tidak ada satu $\beta_{k f}\left(u_{i}, v_{i}\right) \neq \beta_{k f}$ atau

$$
\begin{aligned}
& \delta_{k, m+s}\left(u_{i}, v_{i}\right) \neq \delta_{k, m+s} ; k=1, \ldots, 5 ; f=1 ; \\
& s=1 ; i=1, \ldots, 56
\end{aligned}
$$

Pengujian kesesuaian model antara menggunakan Persamaan (8), diperoleh V(1,756) > $F_{(0,05 ; 21 ; 36)}(1,756)$ atau $p$-value $(0,041)<0,05$ maka keputuskan $\mathrm{H}_{0}$ ditolak. Oleh karena itu terdapat pengaruh faktor geografis pada model yang sesuai digunakan adalah geographically weighted spline nonparametric regression.

\subsection{Uji Signifikansi Parameter Simultan} berikut : 


$$
\begin{aligned}
H_{0}: & \beta_{11}\left(u_{i}, v_{i}\right)=\beta_{1,2}\left(u_{i}, v_{i}\right)=\ldots=\beta_{1,5}\left(u_{i}, v_{i}\right)= \\
& \delta_{1,6}\left(u_{i}, v_{i}\right)=\ldots=\delta_{1,10}\left(u_{i}, v_{i}\right)=0 . \\
H_{1}: & \text { Paling tidak ada satu } \beta_{k f}\left(u_{i}, v_{i}\right) \neq 0 \text { atau } \\
& \delta_{k, m+s}\left(u_{i}, v_{i}\right) \neq 0 ; k=1, \ldots, 5 ; f=1 ; s=1 ; \\
& i=1, \ldots, 56
\end{aligned}
$$

Pengujian signifikansi parameter simultan antara menggunakan Persamaan (9), $V(4,035)>$ $F_{(0,05 ; 55 ; 32)}(1,724)$ atau $p$-value $\left(2,698 \times 10^{-5}\right)<$ 0,05 maka keputuskan $\mathrm{H}_{0}$ ditolak. Sehingga dapat diperoleh kesimpulan bahwa variabel prediktor pada geographically weighted spline nonparametric regression berpengaruh singnifikan terhadap variabel TPT.

\subsection{Uji Signifikansi Parameter Parsial}

Hasil perhitungan dari pengujian signifikansi parameter secara parsial menunjukkan bahwa variabel prediktor yang berpengaruh berbeda-beda untuk setiap area. Hal ini mengakibatkan terdapat 14 kelompok yang terbentuk. Pembagian 14 kelompok yang terbentuk berdasarkan variabel prediktor yang signifikan dapat dijelaskan sebagai berikut :

1. Faktor-faktor yang berpengaruh (TPAK, jumlah penduduk, IPM, HLS dan upah minimum) terhadap TPT (Kelompok 1) dilokasi pengamatan Mempawah, Sanggau, Sintang, Kota Pontianak, Tanah Laut, Kotabaru, Tapin, Pulang Pisau, Gunung Mas, Barito Timur, Kota Palangka Raya, Malinau, Bulungan, Tana Tidung, Kota Nunukan dan Kota Tarakan.

2. Faktor-faktor yang berpengaruh (TPAK, jumlah penduduk, IPM dan HLS) terhadap TPT (Kelompok 2) dilokasi pengamatan Melawi, Kubu Raya, Paser, Penajam Paser Utara dan Kota Balikpapan..

3. Faktor-faktor yang berpengaruh (TPAK, jumlah penduduk, IPM dan upah minimum) terhadap TPT (Kelompok 3) dilokasi pengamatan Barito Kuala dan Kapuas.

4. Faktor-faktor yang berpengaruh (TPAK, jumlah penduduk, HLS dan upah minimum) terhadap TPT (Kelompok 4) dilokasi pengamatan Kotawaringin Timur.

5. Faktor-faktor yang berpengaruh (TPAK, IPM, HLS dan upah minimum) terhadap TPT (Kelompok 5) dilokasi pengamatan Kutai Timur dan Berau.

6. Faktor-faktor yang berpengaruh (TPAK, jumlah penduduk dan HLS) terhadap TPT (Kelompok 6) dilokasi pengamatan Kayong Utara dan Kotawaringin Barat.

Hillidatul Ilmi ${ }^{1}$, Sifriyani ${ }^{2}$, Surya Prangga ${ }^{3}$ /

J Statistika Vol. 14, No. 2, (2021)
7. Faktor-faktor yang berpengaruh (TPAK, IPM dan HLS) terhadap TPT (Kelompok 7) dilokasi pengamatan Kutai Barat, Kota Samarinda dan Kota Bontang.

8. Faktor-faktor yang berpengaruh (Jumlah penduduk, IPM dan upah minimum) terhadap TPT (Kelompok 8) dilokasi pengamatan Hulu Sungai Utara, Barito Selatan, Barito Utara dan murung Raya.

9. Faktor-faktor yang berpengaruh (TPAK dan IPM) terhadap TPT (Kelompok 9) dilokasi pengamatan Sambas, Bengkayang, Kota Singkawang, Kutai Kartanegara dan Mahakam Ulu.

10. Faktor-faktor yang berpengaruh (TPAK dan jumlah penduduk) terhadap TPT (Kelompok 10) dilokasi Seruyan.

11. Faktor-faktor yang berpengaruh (Jumlah penduduk dan HLS) terhadap TPT (Kelompok 11) dilokasi pengamatan Kapuas Hulu

12. Faktor-faktor yang berpengaruh (TPAK dan HLS) terhadap TPT (Kelompok 12) dilokasi Seruyan.

13. Faktor-faktor yang berpengaruh (IPM) terhadap TPT (Kelompok 13) dilokasi pengamatan Hulu Sungai Tengah, Tabalong dan Banjarbaru.

14. Faktor-faktor yang Tidak Signifikan berpengaruh terhadap TPT (Kelompok 14) dilokasi pengamatan Landak, Ketapang, Kota Banjar, Hulu Sungai Selatan, Tanah Bumbu, Kota Banjarmasin, Sukamara, Lamandau dan Katingan.

\section{KESIMPULAN DAN SARAN}

Model geographically weighted spline nonparametric regression dengan pendekatan spline truncated yang terbaik pada data tingkat pengangguran terbuka di Kalimantan Tahun 2019 adalah orde $f=1$ dan titik knot $s=1$. Nilai $R$ squared sebesar 86,410 persen, hal ini mengindikasi bahwa model mampu menjelaskan pengaruh variabel prediktor terhadap variabel respon TPT sebesar 86,410 persen sedangkan 13,590 persen sisanya dijelaskan oleh variabel lain yang tidak diteliti. Hasil pengujian parsial dari estimasi parameter mengelompokkan 56 Kabupaten/Kota menjadi 14 kelompok berdasarkan variabel prediktor yang berpengaruh terhadap TPT di Kalimantan Tahun 2019.

Masing-masing setiap titik lokasi pengamatan 56 Kabupaten/Kota di Kalimantan memiliki model yang berbeda-beda. Salah satu model geographically weighted spline nonparametric regression dari 56 Kabupaten/Kota di Kalimantan yaitu Kabupaten Pulang Pisau yang memiliki TPT terendah dari 56 area di Kalimantan : 


$$
\begin{aligned}
& \hat{y}_{37}=0,009936-0,10157 x_{37,1}-0,30999\left(x_{37,1}-\right. \\
& 71,585)_{+}+1,49 \times 10^{-6} x_{37,2}+5,97 \times 10^{-6}\left(x_{37,2}-\right. \\
& 568100)_{+}+0,16685 x_{37,3}-0,20796\left(x_{37,3}-74,25\right)_{+} \\
& +0,25129 x_{37,4}-0,01111\left(x_{37,4}-13,608\right)_{+}- \\
& 1,42 \times 10^{-6} x_{37,5}+9,82 \times 10^{-6}\left(x_{37,5}-2998900\right)_{+}
\end{aligned}
$$

Interpretasi : Untuk kenaikan TPAK sebesar 1 persen di Kabupaten Pulang maka TPT mengalami kenaikan sebesar 21,479 persen, untuk kenaikan jumlah penduduk sebesar 1.000 jiwa di Kabupaten Pulang maka TPT mengalami kenaikan sebesar 0,009 persen, untuk kenaikan IPM sebesar 1 persen di Kabupaten Pulang maka TPT mengalami kenaikan sebesar 0,031 persen, untuk kenaikan HLS sebesar 1 tahun di Kabupaten Pulang maka TPT mengalami kenaikan sebesar 0,250 persen dan untuk kenaikan upah minimum sebesar Rp1.000.000,00 di Kabupaten Pulang maka TPT mengalami kenaikan sebesar 0,009 persen.

Fungsi pembobot yang digunakan pada penelitian ini yaitu Fungsi kernel Gaussian dan fungsi kernel Bisquare, sehingga untuk penelitian selanjutnya dapat menggunakan pembobot fungsi kernel ekponensial dan fungsi kernel Tricube. Data yang digunakan pada penelitian ini adalah data tahun 2019. Untuk penelitian selanjutnya dapat menggunakan data keluaran terbaru.

\section{DAFTAR PUSTAKA}

Demsar, Fotheringham dan Charlton, 2008, Exploring the spatio-temporal dynamics of geographical processes with geograhically weighted regression and geovisual analytics, Inference Vis, 7. 181-197.

BPS Kalimantan Barat. (2019). Keadaan Angkatan Kerja. Badan Pusat Statistik Provinsi Kalimantan Barat.

BPS Kalimantan Barat. (2020a). Provinsi Kalimantan Barat dalam Angka. Badan Pusat Statistik Provinsi Kalimantan Barat.

BPS Kalimantan Barat. (2020b). Proyeksi Penduduk Kabupaten/Kota. Badan Pusat Statistik Provinsi Kalimantan Barat.

BPS Kalimantan Selatan. (2019). Keadaan Angkatan Kerja. Badan Pusat Statistik Provinsi Kalimantan Selatan.

BPS Kalimantan Selatan. (2020). Provinsi Kalimantan Selatan dalam Angka. Badan Pusat Statistik Provinsi Kalimantan Selatan.
BPS Kalimantan Tengah. (2019a). Keadaan Angkatan Kerja. Badan Pusat Statistik Provinsi Kalimantan Tengah.

BPS Kalimantan Tengah. (2019b). Statistika Ketenagakerjaan. Badan Pusat Statistik Provinsi Kalimantan Tengah.

BPS Kalimantan Tengah. (2020a). Provinsi Kalimantan Tengah dalam Angka. Badan Pusat Statistik Provinsi Kalimantan Tengah.

BPS Kalimantan Tengah. (2020b). Proyeksi Penduduk Kabupaten/Kota. Badan Pusat Statistik Provinsi Kalimantan Tengah

BPS Kalimantan Timur. (2019a). Keadaan Angkatan Kerja. Badan Pusat Statistik Provinsi Kalimantan Timur.

BPS Kalimantan Timur. (2019b). Indeks Pembangunan Manusia. Badan Pusat Statistik Provinsi Kalimantan Timur.

BPS Kalimantan Timur. (2020). Provinsi Kalimantan Timur dalam Angka. Badan Pusat Statistik Provinsi Kalimantan Timur.

BPS Kalimantan Utara. (2019). Keadaan Angkatan Kerja. Badan Pusat Statistik Provinsi Kalimantan Utara.

BPS Kalimantan Utara. (2020). Provinsi Kalimantan Utara dalam Angka. Badan Pusat Statistik Provinsi Kalimantan Utara.

Dinas Ketenagakerjaan. (2020). Penetapan Upah Minimum. Dinas Ketenagakerjaan Kalimantan Barat.

Dinas Ketenagakerjaan. (2020). Upah Minimum Regional. Dinas Ketenagakerjaan Kalimantan Tengah.

Draper dan Smith. (1992). Applied Regression Analysis, Second Edition. New York: John Wiley \& Sons.

Eubank, R.L. (1998). Spline Smoothing and Nonparametric Regression. New York: Marcel Dekker.

Fortheringham, A.S., Brundson, C dan Charlton, M. (2002). Geoghraphically Weighted Regression. New York: John Wiley and Sons.

Huang, Wu, dan Barry, 2010, Geographically and temporally weighted regression for modeling spatio-temporal variation in house prices. International Journal Geographical Inference Science. 24, 383-401.

Kosfeld, Reinhold. (2006). Spatial Econometric. Institute of Economics. University of Kassel.

Mei, Wang dan Zhang, 2006, Testing the importance of the explanatory variables in a mixed geographically weighted regression model, Journal Environment and Planning, 38(3), 587-598. 
J Statistika Vol. 14, No. 2, (2021), Hal. 84-92

Nakaya, Fotheringham, Brunsdon dan Charltron, 2005, Geographically Weighted Poisson Regression for disease association mapping, Journal Statistics Medicine, 24(17), 26952717

Sifriyani., Haryatmi., Budiantara, I.N dan Gunardi.. (2018a). Development of Nonparametric Geographically Weighted Regression Using Truncated Spline Approach. Songklanakarin J. Sci. Technol, Vol. 40(4), pp. 909-920.

Sifriyani., Haryatmi., Budiantara, I.N dan Gunardi.. (2018a). (2018b). A New Method of Hypotesis Test for Truncated Spline Nonparametric Regression Influenced by Spatial Heterogenity and Application. Abstract and Applied Analysis, 2018. doi: 10.1155/2018/9769150.

Sifriyani, Ruslan, F.H. Susanty. 2019(a). Evaluation of Forest Productivity and Governance on the Preservation of Tropical Rain Forests in Kalimantan Using The NGWR-TS Nonparametric Geospatial Method. EurAsian Journal of BioSciences, Vol 13 Issue 2, pp. 2373-2379.

Sifriyani, Ruslan, F.H. Susanty. 2019(b). Mapping and Analysis Factors of Affecting Productivity Tropical Rain Forests in East Kalimantan, Modern Applied Science, Vol 13 No 10, DOI: 10.5539/mas.v13n10p112

Sifriyani, Budiantara, I. N., Kartiko, S.H., and Gunardi. (2019). Evaluation of Factors Affecting Increased Unemployment in East Java Using NGWR-TS Method, International Journal of Sciences: Basic and Applied Research. 49(1), 123-142.

Yu, D., 2010, Exploring spatiotemporally varying regressed relationships: the geographically weighted panel regression analysis. Proceedings of the Joint International Conference on Theory, Data Handling and Modeling in GeoSpatial Information Science, 134-139.

Hillidatul Ilmi ${ }^{1}$, Sifriyani ${ }^{2}$, Surya Prangga ${ }^{3} /$

J Statistika Vol. 14, No. 2, (2021) 